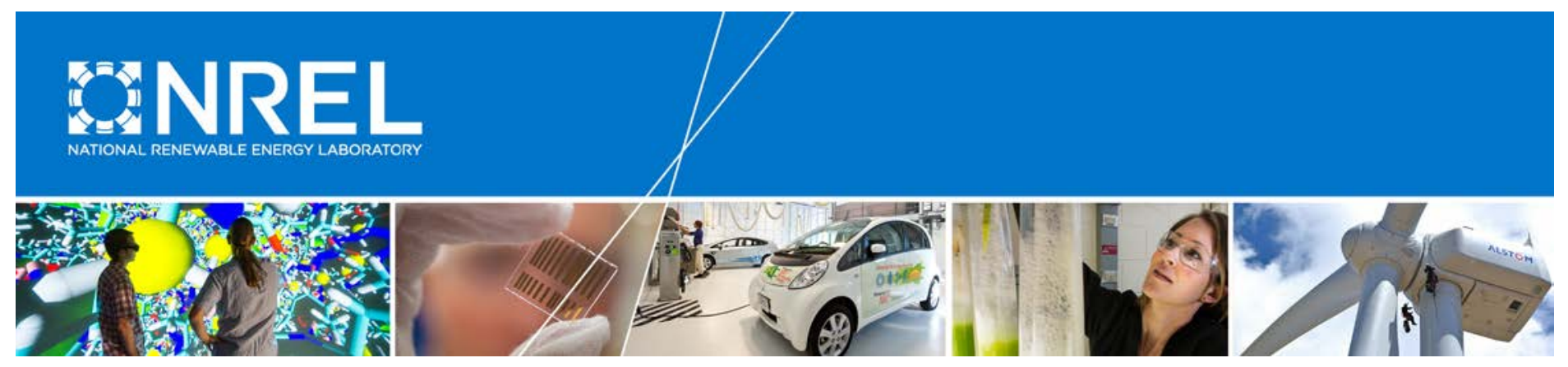

\title{
Solar Lending Practices by Community and Regional Financial Institutions
}

Paul Schwabe and David Feldman National Renewable Energy Laboratory

NREL is a national laboratory of the U.S. Department of Energy Office of Energy Efficiency \& Renewable Energy Operated by the Alliance for Sustainable Energy, LLC

This report is available at no cost from the National Renewable Energy Laboratory (NREL) at www.nrel.gov/publications.

Technical Report

NREL/TP-6A20-71753

June 2018

Contract No. DE-AC36-08GO28308 


\title{
Solar Lending Practices by Community and Regional Financial Institutions
}

\author{
Paul Schwabe and David Feldman \\ National Renewable Energy Laboratory
}

NREL is a national laboratory of the U.S. Department of Energy Office of Energy Efficiency \& Renewable Energy Operated by the Alliance for Sustainable Energy, LLC

This report is available at no cost from the National Renewable Energy Laboratory (NREL) at www.nrel.gov/publications.

National Renewable Energy Laboratory 15013 Denver West Parkway Golden, CO 80401

303-275-3000 • www.nrel.gov

\section{Technical Report}

NREL/TP-6A20-71753

June 2018

Contract No. DE-AC36-08G028308 


\section{NOTICE}

This work was authored in part by the National Renewable Energy Laboratory, operated by Alliance for Sustainable Energy, LLC, for the U.S. Department of Energy (DOE) under Contract No. DE-AC3608GO28308. Funding provided by the U.S. Department of Energy Office of Energy Efficiency and Renewable Solar Energy Technologies Office. The views expressed in the article do not necessarily represent the views of the DOE or the U.S. Government.

This report is available at no cost from the National

Renewable Energy Laboratory (NREL) at

www.nrel.gov/publications.

U.S. Department of Energy (DOE) reports produced

after 1991 and a growing number of pre-1991

documents are available

free via www.OSTI.gov.

Cover Photos by Dennis Schroeder: (left to right) NREL 26173, NREL 18302, NREL 19758, NREL 29642, NREL 19795.

NREL prints on paper that contains recycled content. 


\section{Acknowledgments}

The authors would like to thank the invaluable contributions from Kelsey Read and Andrew Belden from Massachusetts Clean Energy Center as well as the following individuals and organizations for their insightful perspectives and review comments: Justin Allender of First Green Bank; Sean Baird of Medallion Bank; Carol Chernikoff of Alternatives Credit Union; Ron Felder of Redwood Credit Union; Jasna Filipović and Justin Fuller of Celtic Bank; Phillip Forbert, Lance Griswold, and Danielle Silva of U.S. Eagle Credit Union; Kyle Henderson of FirstBank; Sarah Llewellyn and Chad Tomsich of Elevations Credit Union; David Miller and Pete Yang of Alpine Bank; Scott Pellegrini of Provident Credit Union; Steve Sherman formerly of GreenChoice Bank; Bob Schweigert of Salal Credit Union; and Skyler Webster of New Resource Bank. The authors also thank Jarett Zuboy for his superb editorial support and Eric O’Shaughnessy and Billy Roberts for their help with graphics.

This work was authored by the National Renewable Energy Laboratory, operated by Alliance for Sustainable Energy, LLC, for the U.S. Department of Energy (DOE) under Contract No. DE-AC3608GO28308. Funding provided by the Solar Energy Technologies Office of the U.S. Department of Energy's Office of Energy Efficiency and Renewable Energy. The views expressed in the article do not necessarily represent the views of the DOE or the U.S. Government. 


\section{List of Acronyms}

CRFI

FDIC

FICO

HELOC

ITC

MassCEC

NCUA

NREL

PACE

PPA

PV

SREC

TPO

UCC community and regional financial institution

Federal Deposit Insurance Corporation

Fair Isaac Corporation (credit score)

home equity line of credit

investment tax credit

Massachusetts Clean Energy Center

National Credit Union Administration

National Renewable Energy Laboratory

property assessed clean energy

power-purchase agreement

solar photovoltaic

Solar Renewable Energy Certificate

third-party ownership

Uniform Commercial Code 


\section{Executive Summary}

Current projections of solar photovoltaic (PV) system costs and deployment in the United States indicate substantial capital requirements over the next 30 years and beyond. The U.S. Energy Information Administration estimates that, from 2019 to 2050, approximately $\$ 650$ billion will be spent on U.S. PV system deployment (EIA 2018). Concurrently, community and regional financial institutions (CRFIs), including community banks and credit unions, collectively hold \$3.6 trillion in assets. These institutions could provide a significant portion of the required PV capital while creating a large investment opportunity for themselves. Accelerating the involvement of CRFIs in the PV financial marketplace would increase the total amount of capital available for PV projects and broaden the types of financing products used.

From 2012 to 2014, third-party-ownership (TPO) of residential PV systems, including leases and power-purchase agreements represented $62 \%$ to $72 \%$ of the U.S. market. Beginning in 2015, TPO market share decreased while PV loans and cash purchases grew. By 2017, TPO fell to 41\% of annual installations while loans made up 33\% of the market (the remainder were direct purchases). The increase in PV loans and cash purchases was due to several factors, including declining PV system costs, more widespread loan availability, and changing business models of national installers among other reasons (Mond 2018). The shift towards PV loans has allowed new, smaller financiers such as CRFIs to enter the PV financing market.

CRFIs typically offer PV financing via loans to small residential and commercial borrowers. A sampling of CRFI perspectives collected from industry interviews indicates positive experiences with the development and evolution of PV loans. Quantitative data on 6,770 loans representing over \$186 million in lending also suggest PV loans are performing very well to date-although these results must be put in the context of the high credit quality of borrowers, early state of the loans, and recent robust economy (Table ES-1). The strong performance to date suggests continued expansion of loan offerings by CRFIs already operating in this space and likely attraction of new entrants. Although most CRFI investment has targeted distributed PV without storage, other applications will likely emerge, such as community PV and PV coupled with energy storage. Looking ahead, access to additional credit and market information is critical for accelerating the role of CRFIs and other financial institutions in supporting U.S. PV growth.

Table ES-1. PV Loan Sample Summary Statistics by CRFI Portfolio Size

\begin{tabular}{lccccccccccc}
\hline $\begin{array}{l}\text { PV loan } \\
\text { portfolio } \\
\text { (million) }\end{array}$ & $\begin{array}{c}\text { No. of } \\
\text { CRFIs }\end{array}$ & $\begin{array}{c}\text { Total } \\
\text { loans }\end{array}$ & $\begin{array}{c}\text { No. of } \\
\text { loans }\end{array}$ & $\begin{array}{c}\text { Avg. } \\
\text { seasoning } \\
\text { in } \\
\text { months }\end{array}$ & $\begin{array}{c}\text { FICO } \\
\mathbf{2} 720\end{array}$ & $\begin{array}{c}\text { FICO } \\
\mathbf{6 8 1 -}\end{array}$ & $\begin{array}{c}\text { FICO } \\
\mathbf{7 1 9}\end{array}$ & $\begin{array}{c}\text { Charge- } \\
\text { offs }\end{array}$ & $\begin{array}{c}\mathbf{3 0} \\
\text { days } \\
\text { late }\end{array}$ & $\begin{array}{c}\mathbf{6 0} \\
\text { days } \\
\text { late }\end{array}$ & $\begin{array}{c}\mathbf{9 0} \\
\text { days } \\
\text { late }\end{array}$ \\
\hline$>\$ 10$ & 6 & $\$ 138,699,859$ & 4,929 & 12 & $78 \%$ & $14 \%$ & $8 \%$ & 10 & 171 & 61 & 24 \\
\hline$>\$ 5-\$ 10$ & 4 & $\$ 30,867,895$ & 1,091 & 13 & $82 \%$ & $11 \%$ & $6 \%$ & 0 & 4 & 0 & 0 \\
$>\$ 1-\$ 5$ & 6 & $\$ 13,886,826$ & 658 & 14 & $76 \%$ & $12 \%$ & $11 \%$ & 2 & 0 & 0 & 0 \\
\hline$<1$ & 6 & $\$ 2,851,725$ & 92 & 4 & $88 \%$ & $9 \%$ & $3 \%$ & 0 & 3 & 0 & 0 \\
\hline Totals & $\mathbf{2 2}$ & $\mathbf{\$ 1 8 6 , 3 0 6 , 3 0 5}$ & $\mathbf{6 , 7 7 0}$ & & & & & $\mathbf{1 2}$ & $\mathbf{1 7 8}$ & $\mathbf{6 1}$ & $\mathbf{2 4}$ \\
\hline
\end{tabular}

Source: Mass Solar Loan (2018) and individual CRFI contributions 


\section{Table of Contents}

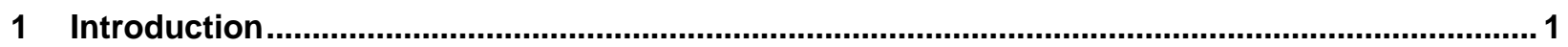

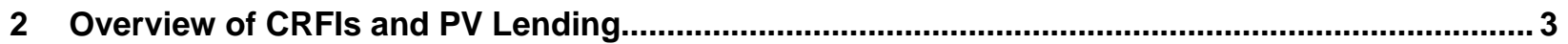

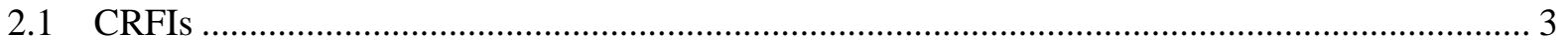

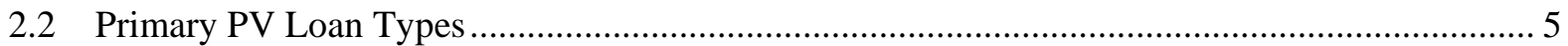

3 Themes about PV Loan Products from CRFI Interviews ........................................................ 9

3.1 Market Demand, Institutional Philosophy, and Comfort with Home-Improvement Loans Drive

PV Loan Product Development.................................................................................................. 9

3.2 PV Loan Product Development Benefits from a Thoughtful Research, Approval, and Product-

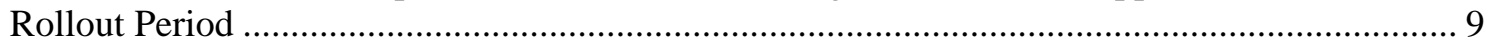

3.3 Smaller CRFIs Possess Unique Challenges and Opportunities............................................... 10

3.4 PV Loan Products and Processes Vary across Institutions ....................................................... 11

3.5 UCC-1 Fixture Filing Is Useful as a Security Interest, but Repossessing PV Systems Is

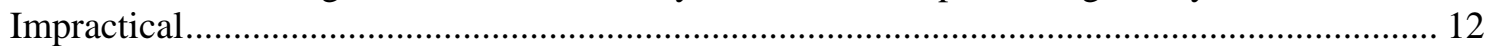

3.6 PV Loan Repayment Has Been Strong, but Most Loans Are Young and Were Made to Highly

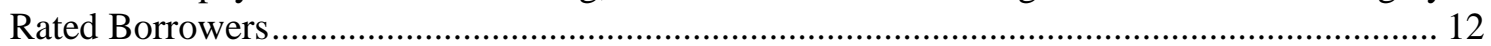

3.7 Relationships between PV Installers and CRFIs Can Enhance the Marketing of PV Loan

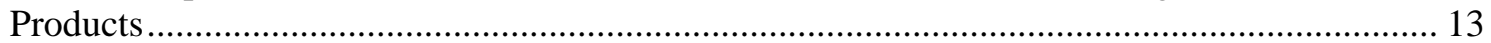

3.8 CRFIs Are Willing to Extend PV Loans to Lower-Rated Borrowers, but Barriers Exist ........... 14

3.9 PV Energy Savings Are Generally Given Little Weight during Loan-Approval Processes ....... 14

3.10 Regulations Have Not Hindered PV Loans, but Educating Regulators about PV May Help ..... 15

3.11 Challenges Remain for PV Loan Products ............................................................................... 15

4 Quantitative Indicators of PV Loan Performance........................................................................ 17

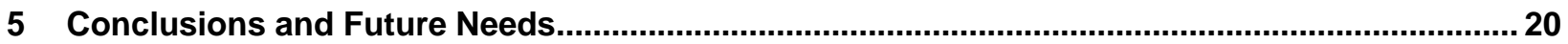

References ....................................................................................................................................................21 


\section{List of Figures}

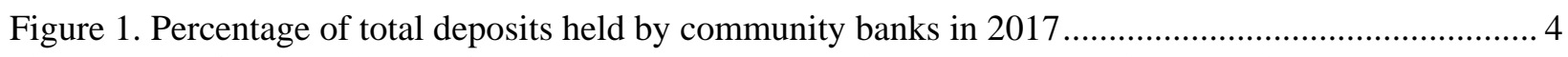

Figure 2. Portfolio breakdown for loans made by community banks and credit unions in 2017................. 5

Figure 3. Variations in PV loan types by level of security ..................................................................... 7

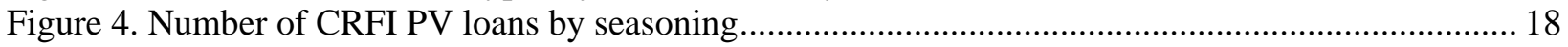

Figure 5. Credit score summary across entire sample of borrowers ......................................................... 19

\section{List of Tables}

Table ES-1. PV Loan Sample Summary Statistics by CRFI Portfolio Size ............................................. iv

Table 1. Bank Assets, Loans, and Number of Institutions in the United States ........................................... 3

Table 2. PV Loan Sample Summary Statistics by CRFI Portfolio Size ................................................. 17 


\section{Introduction}

Current projections of solar photovoltaic (PV) system costs and deployment in the United States indicate substantial capital requirements over the next 30 years and beyond. The U.S. Energy Information Administration estimates that, from 2019 to 2050, approximately $\$ 650$ billion will be spent on U.S. PV system deployment (EIA 2018). Concurrently, community and regional financial institutions (CRFIs), including community banks and credit unions, collectively hold $\$ 3.6$ trillion in assets. These institutions could provide a significant portion of the required PV capital while creating a large investment opportunity for themselves. Accelerating the involvement of CRFIs in the PV financial marketplace would increase the total amount of capital available for PV projects and broaden the types of financing products used.

PV systems installed in the United States vary considerably in terms of size, location, and procurement mechanism. Large, centralized PV systems constitute most of the country's total installed PV capacity, but the greatest number of PV systems are distributed projects located on residential or commercial property (95.4\% and 4.5\% of U.S. PV systems, respectively) (SEIA and GTM Research 2018). Because each individual project represents a relatively small financial investment, some businesses have aggregated numerous projects to increase the size and attractiveness of distributed PV investments. Over the past 10 years, distributed PV markets have grown considerably; in 2017 alone, investment in U.S. distributed PV systems totaled over \$10 billion (SEIA and GTM Research 2018).

From 2012 to 2014, third-party-ownership (TPO) of residential PV systems, including leases and power-purchase agreements represented $62 \%$ to $72 \%$ of the U.S. market. Beginning in 2015, TPO market share decreased while PV loans and cash purchases grew. By 2017, TPO fell to 41\% of annual installations while loans made up 33\% of the market (the remainder were direct purchases). The increase in PV loans and cash purchases was due to several factors, including declining PV system costs, more widespread loan availability, and changing business models of national installers among other reasons (Mond 2018).

The shift toward host ownership of PV systems has allowed new, smaller financiers — such as CRFIs - to enter the market, including lenders dedicated to small residential and commercial projects. The TPO market presents barriers to many small lenders, particularly as TPO projects often require complex investment structures with outside tax-equity investors to capture the value of the investment tax credit (ITC). ${ }^{1}$ Providing loans rather than leases and power-purchase agreements plays to the strengths of many CRFIs as solar loans are like other CRFI products and because complex financial structuring is not required to use the ITC, which remains with the homeowner.

This report therefore examines the experiences and perspectives of CRFIs that have developed and launched PV loan products, including the evolution of the products and their performance.

\footnotetext{
${ }^{1}$ Given the limited number of tax-equity investors participating in the U.S. market, and the premium they can charge for many projects with limited options, there may be a role for some CRFIs in this space. That said, the federal wind and solar tax credits are scheduled to phase down over the next few years, so institutions may decide not to invest resources into learning how to structure these complex financial transactions with potentially limited availability.
} 
This information could assist other CRFIs that are considering participating in or expanding their role in PV financing.

The remainder of this report is organized as follows. Section 2 gives an overview of U.S. CRFIs and the financial products they typically offer. Section 3 provides CRFI perspectives about their experiences with PV financing products based on industry interviews. Section 4 presents quantitative data on PV loan performance and borrower credit profiles. Section 5 concludes and identifies future needs related to expansion of PV lending. ${ }^{2}$

\footnotetext{
2 The National Renewable Energy Laboratory (NREL) has conducted previous PV-financing research. From 20132015, the Solar Access to Public Capital project examined how a securitization market for TPO PV allowed national-level players to increase PV project capital by attracting institutional and retail investors (NREL 2018). NREL also compared PV loans with other TPO products such as PPAs and leases (Feldman and Lowder 2014). This previous research focused on financial products rather than types of financial institutions.
} 


\section{Overview of CRFIs and PV Lending}

This section first discusses the importance of CRFIs in facilitating community investments and then briefly describes the characteristics of PV loan types. Here CRFIs include community banks insured by the Federal Deposit Insurance Corporation (FDIC) and credit unions insured by the National Credit Union Administration (NCUA). ${ }^{3}$

\subsection{CRFIS}

Table 1 shows the sizes and numbers of U.S. banks and credit unions. FDIC-insured community banks and NCUA-insured credit unions account for approximately 19\% of all bank assets (\$3.6 trillion), $24 \%$ of all bank loans (\$2.6 trillion), and $96 \%$ of U.S. banking institutions $(10,911$ institutions).

Table 1. Bank Assets, Loans, and Number of Institutions in the United States

\begin{tabular}{|lccc|}
\hline & $\begin{array}{c}\text { Assets in } \$ \\
\text { trillions } \\
(\% \text { of total) }\end{array}$ & $\begin{array}{c}\text { Loans in } \$ \\
\text { trillions } \\
(\% \text { of total) }\end{array}$ & $\begin{array}{c}\text { Number of } \\
\text { institutions } \\
\text { (\% of total) }\end{array}$ \\
\hline FDIC-insured non-community banks & $\$ 15.3(81.0 \%)$ & $\$ 8.2(76.6 \%)$ & $443(3.9 \%)$ \\
\hline FDIC-insured community banks & $\$ 2.2(11.6 \%)$ & $\$ 1.6(15.0 \%)$ & $5,227(46.0 \%)$ \\
\hline NCUA-insured credit unions & $\$ 1.4(7.4 \%)$ & $\$ 1.0(9.3 \%)$ & $5,684(50.1 \%)$ \\
\hline Total & $\$ 18.9$ & $\$ 10.7$ & 11,354 \\
\hline
\end{tabular}

Sources: CUNA (2017), FDIC (2017, 2018)

The FDIC defines community banks as those that "focus on providing traditional banking services in their local communities. They obtain most of their core deposits locally and make most of their loans to local businesses” (FDIC 2012). Further, CRFIs are often considered "relationship" lenders rather than "transaction" lenders. Community banks can be apt to make credit decisions based on local knowledge and unique data obtained through long-term relationships owing to their deep understanding of local market dynamics (FDIC 2012). Small businesses may rely more heavily on this relationship approach, because they may be challenged to qualify for loans based on the more rigid, standardized qualification parameters of noncommunity banks (FDIC 2012). Community banks are frequently privately owned and locally controlled, which may balance the competing interests of shareholders, customers, employees, and the local community. This is also true for credit unions, which are owned by their members and operate for the sole purpose of servicing their members. Larger banks are more likely to be publicly owned and tend to have stronger associations with the capital markets. They also operate in more places with centralized and model-based loan-approval structures. (FDIC 2012).

Community banks are particularly important and prevalent in certain regions of the country. In 2014, community banks held $72 \%$ of deposits in U.S. rural counties and 56\% of deposits in

\footnotetext{
${ }^{3}$ Some CRFIs operate certain business lines, such as direct lending, in more than one market, while other business lines, such as retail banking, can be restricted to a smaller geographic footprint. This report does not exclude CRFIs even if a business line is operated in more than one market.
} 
micro-counties (FDIC 2015). ${ }^{4}$ Many states with a large community banking presence are in the middle of the country, where PV penetration tends to be relatively low (Figure 1).${ }^{5}$ CRFIs could close this gap by providing financial solutions that help make distributed PV economically attractive in their region.

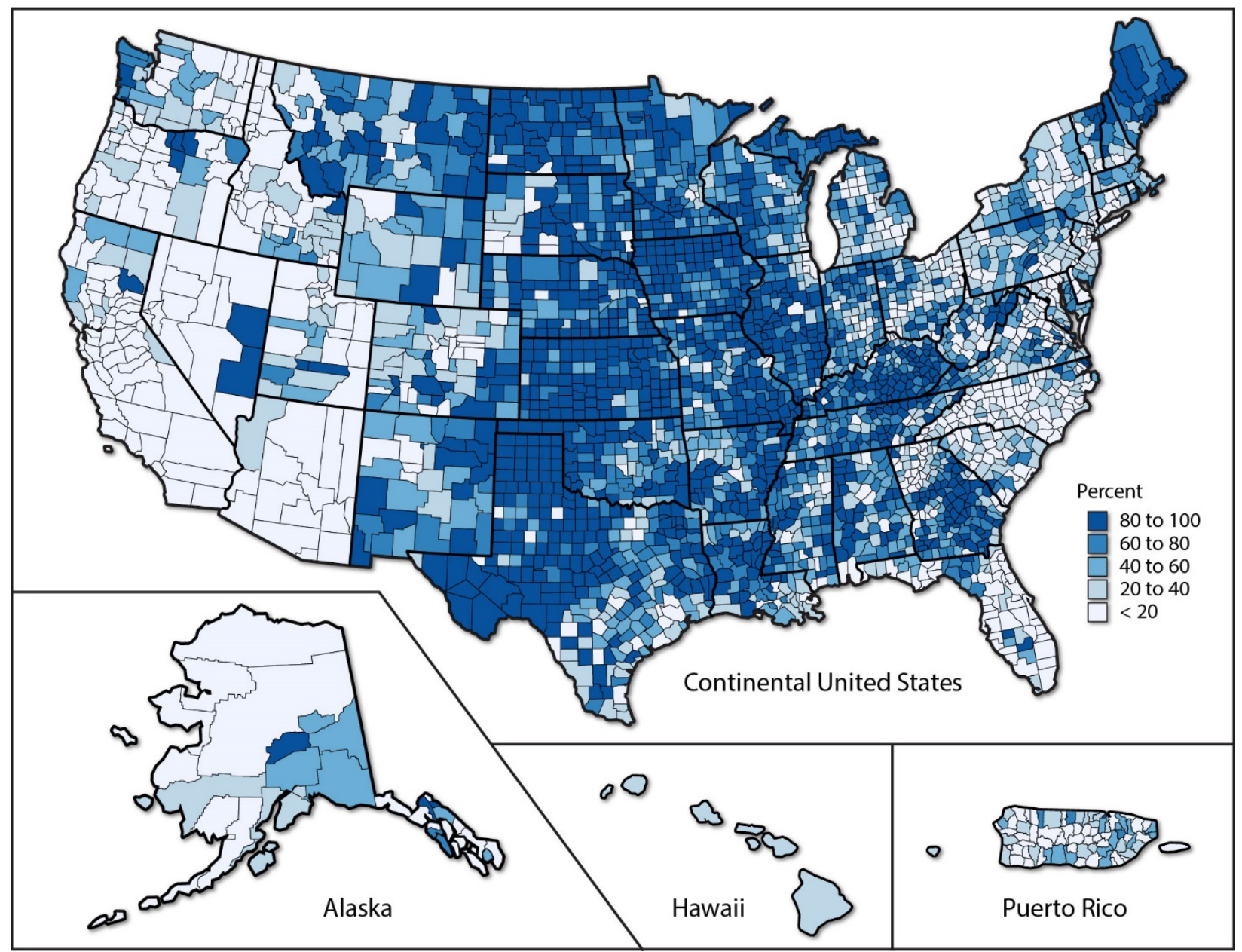

Figure 1. Percentage of total deposits held by community banks in 2017

Source: FDIC (2018)

Because of their size, geographic variation, and local market knowledge, CRFIs are well suited to develop innovative or tailored PV financing products. Relatively few banking institutions currently offer PV loan products, and existing product specifications might not be desirable in every market. However, new PV loan products could be developed for many of the communities served by CRFIs, and the willingness of many CRFIs to collaborate and share could enable rapid dissemination and evolution of the new products.

${ }^{4}$ Rural counties are defined as those with a population of less than 10,000 people. Micro-counties are defined as having between 10,000 and 50,000 people (FDIC 2012).

${ }^{5}$ Data as of June 30, 2017. 
Many CRFI loan types could be adapted for financing PV systems. As shown in Figure 2, most community bank loans are for commercial and residential real estate (70\%), followed by commercial and industrial activities (13\%), construction and development (7\%), and unsecured loans to individuals (4\%). ${ }^{6}$ Credit unions generally focus more on individual customers and less on commercial activities, with $83 \%$ of their loans made for residential real estate or automobiles, $7 \%$ for commercial and industrial activities, and 10\% for unsecured loans to individuals. Distributed PV systems are usually physically attached to real estate, much like many homeimprovement projects (e.g., roof replacements, kitchen remodeling), which are often funded through real estate loans. A 2018 Federal Reserve Bank of New York study found that 56\% of home equity lines of credit (HELOCs) and 72\% of home equity loans - types of real estate loans - were used to make home improvements (Fuster et al. 2018). In the commercial space, a PV system is like other equipment financings and could be funded by commercial and industrial loans. Finally, because the cost of PV systems has fallen dramatically, loans made to an individual on an unsecured basis may also fund a PV project. Although unsecured loans to individuals represent a relatively small portion of CRFI loan portfolios, they still constituted over $\$ 160$ billion at the end of 2017 (see Table 1 and Figure 2).

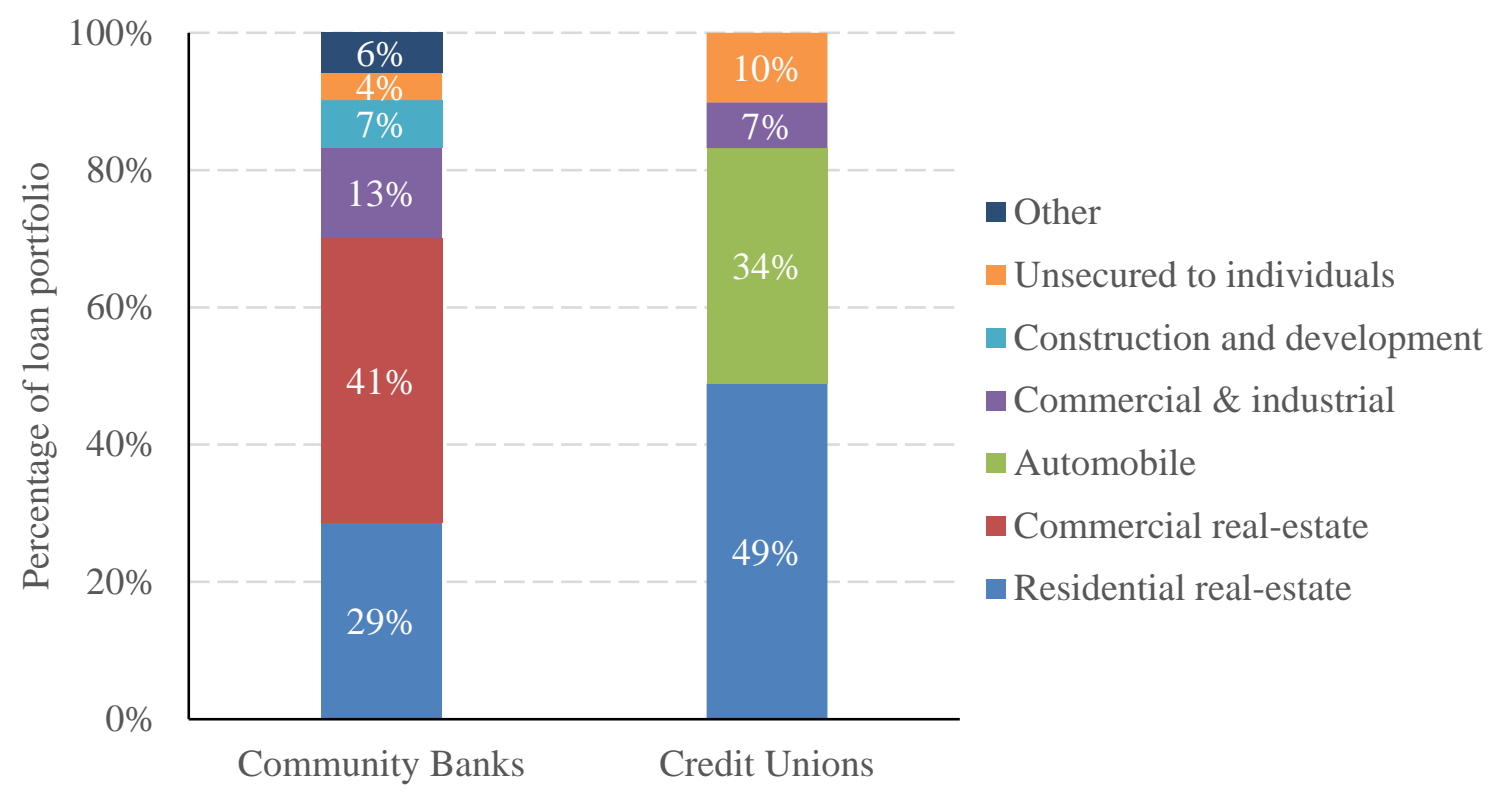

Figure 2. Portfolio breakdown for loans made by community banks and credit unions in 2017 Sources: CUNA (2017), FDIC (2018)

\subsection{Primary PV Loan Types}

PV loans generally fall into a few categories, with variations. As shown in Figure 3, PV loans can be classified by their level of security, based on what the borrower pledges as collateral for

\footnotetext{
${ }^{6}$ An unsecured loan is a loan issued based on the creditworthiness of the individual, rather than being based on collateral such as real estate equity.
} 
the loan. PV loans have typically been secured by real estate, by the equipment itself through a Uniform Commercial Code (UCC)- 1 filing, ${ }^{7}$ or as an unsecured personal loan. ${ }^{8}$

- Loan secured on real estate-PV loans can be secured via the underlying real estate, typically, in the residential space, through a home equity loan (also referred to as a second mortgage) or a HELOC. ${ }^{9}$ Like other real estate loans, they require a closing, or settlement, at which all parties sign the necessary loan documents. To get to closing, the real estate typically is appraised to ensure the owner has sufficient equity in the property, the loan is registered with the county clerk, and taxes are evaluated. This is a heavily regulated process, particularly since the recent mortgage crisis. Obtaining a real estate loan requires time and money, but borrowers can often get a relatively low rate compared with the rates of other types of loans. ${ }^{10}$ Real estate loans typically carry longer repayment terms, which allows PV system owners to match the loan payments more closely with the energy cost savings from the PV system.

- Loan secured on equipment ${ }^{11}$ - Many PV loan providers secure the loan through a UCC-1 filing with the county or state (or both) of the borrower, which gives notice of the lender's lien (also referred to as a security interest) on the PV property, but importantly not on the underlying real estate. The UCC-1 filing gives the lender certain rights, such as repossession of the PV system itself until the loan is repaid. UCC-1 filings require less upfront time, money, and paperwork compared with real estate loan processes, but the UCC-1 security interest still comes up in a title search, which is typically conducted when a property is sold or refinanced. That said, the solar lender may have difficulty recouping the value of the PV system in the case of repossession, and the UCC-1 filing must be re-registered periodically. For these reasons, many lenders consider solar loans with UCC-1 filings as not fully secured.

- Unsecured loan-With an unsecured loan, the lender holds no collateral but instead makes the loan based on an individual's credit quality, income, and debt level. Such loans can be closed more easily and quickly than other loans, but the interest rate charged is typically higher and with a shorter term than the rate and term of a secured loan. In addition, unsecured loans are usually only available to borrowers with good credit or a high income and with limited outstanding debt.

\footnotetext{
${ }^{7}$ UCC-1 refers to Form 1 (UCC Financing Statement) (IACA 2018).

${ }^{8}$ In some instances, banks have also secured loans using incentive streams generated by PV assets, such as Solar Renewable Energy Certificates (SRECs). This option is only available in markets with SRECs of sufficient value and is dependent on the PV asset continuing to generate electricity (to produce SRECs).

${ }^{9}$ HELOCs typically have a drawdown period with a floating interest rate. Funds from second mortgages are received at the beginning of the loan, and the loan is more likely to have a fixed rate.

10 The interest payments on home equity loans and HELOCs can be tax deductible under certain qualifying uses. Generally, the home equity loan or HELOC is borrowed for home-improvement purposes, and the total of the borrower's first mortgage and their home equity loan or HELOC does not exceed \$750,000. The Tax Cut and Jobs Act of December 2017 lowered this interest deduction cap from \$1,100,000 to \$750,000 and narrowed the allowable uses to primarily home-improvement related. Given these changes, it is possible that demand for home equity loans and HELOCs may fall, particularly in markets with comparatively high home prices and a higher probability of reaching the \$750,000 combined interest deduction cap (Harney 2018).

${ }^{11}$ May also be referred to as a chattel loan. Although PV equipment is technically considered collateral, the practicality and cost effectiveness of physically removing the equipment from the property remains an open question (see Section 3.5).
} 


\section{RESIDENTIAL}

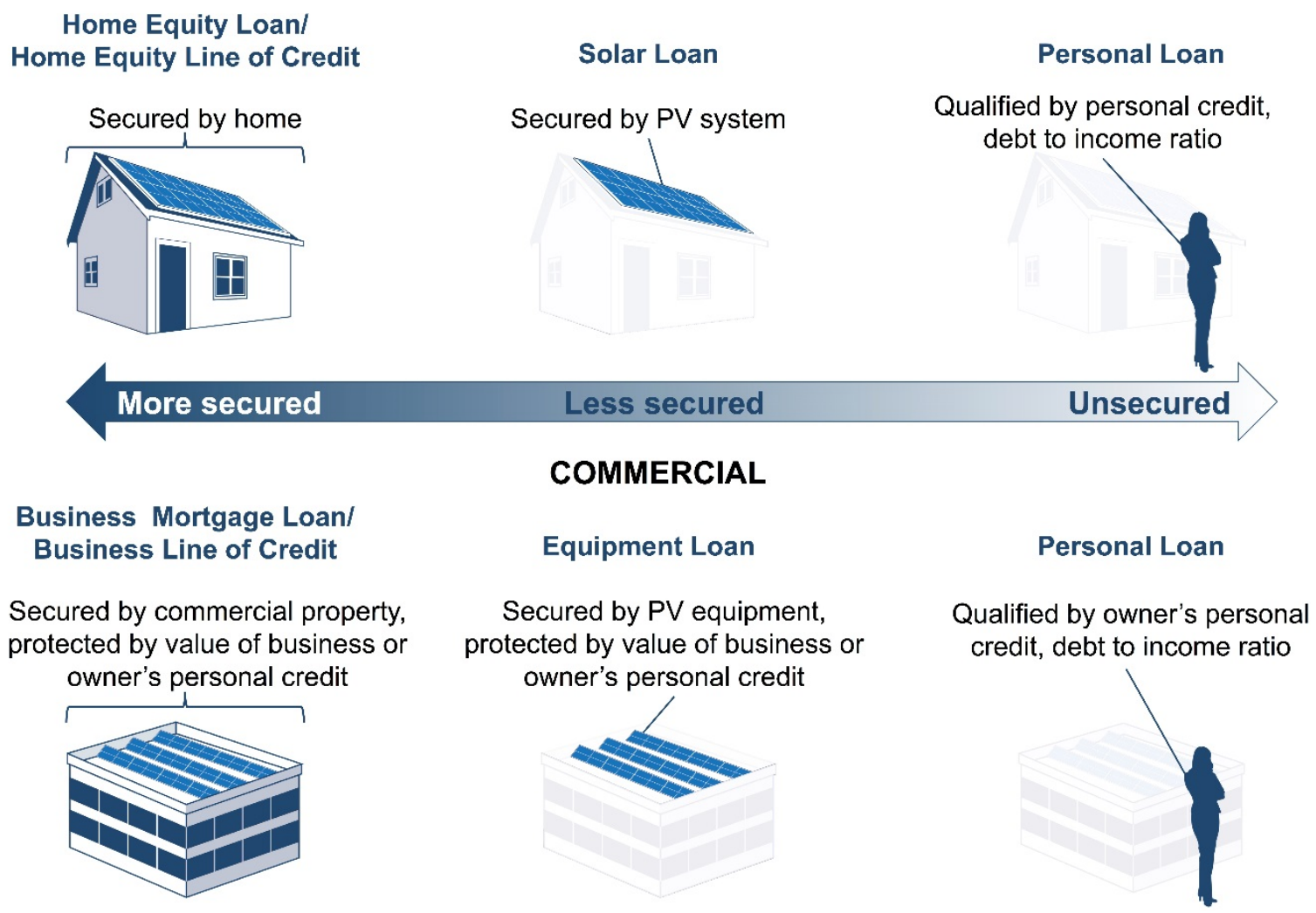

Figure 3. Variations in PV loan types by level of security

In addition to level of security, PV loans can be characterized by several criteria:

- Tenor (loan length) —Because PV assets are long-lived, it is often advantageous for a PV loan to have a longer tenor. A longer tenor reduces the amount of each periodic payment, potentially aligning the loan payment more closely with the PV energy savings. Some UCC-1 loans and personal, unsecured loans have relatively short tenors, but some banks have lengthened the tenor as their programs have evolved. For this reason, PV loan tenors can vary from 3-20 years.

- Prepayment and reamortization ${ }^{12}$ - Some loans have prepayment penalties to compensate lenders for receiving fewer interest payments over the course of the loan. PV systems currently benefit from the 30\% federal ITC, typically taken in the first year of operation. Therefore, PV system owners often get 30\% of the system cost back very early in the loan. Many PV loans offer a one-time low or no-fee prepayment option, which the borrower can use to buy down the outstanding principal using the ITC, or no prepayment penalty over the life of the loan. Some borrowers also reamortize the loan after the prepayment to reduce monthly debt payments further.

\footnotetext{
${ }^{12}$ Reamortization is the process of recalculating the monthly loan payment amount while keeping the same original schedule of loan payments (i.e., tenor). A loan is typically reamortized when a significant portion of its principal is paid.
} 
- Government involvement-Many banks have introduced PV loan products based on market conditions without government financial support, but some loan products have benefited from state or federal government programs. Some state agencies have helped banks set up PV loan products and provided technical expertise to get banks comfortable with PV as an asset class. Other programs have subsidized the cost of PV loans by offering credit support (guaranteeing all or some of the loan amount), buying down the interest rate of a loan, or buying down the cost of a PV project (reducing the loan principal, typically through rebates). These programs are often instituted to establish or accelerate a market or to provide loans to customers who may not otherwise qualify (e.g., individuals with low income). ${ }^{13}$

\footnotetext{
${ }^{13}$ Local governments are also heavily involved in property assessed clean energy (PACE) programs, which offer commercial and residential customers loans that are tied to their property taxes.
} 


\section{Themes about PV Loan Products from CRFI Interviews}

This section summarizes the themes from in-depth interviews with 20 PV financing experts from 14 CRFIs or related stakeholder institutions, describing shared and diverse experiences of PV financing products. Themes arising from more than one institution or individual are included, and no approach is presented as favorable. The themes are described loosely in chronological order, starting with product initiation, followed by operational experiences, and concluding with forward-looking perspectives.

\subsection{Market Demand, Institutional Philosophy, and Comfort with Home-Improvement Loans Drive PV Loan Product Development}

In addition to the shifting PV market trends described earlier, PV loan products are frequently initiated in response to customer or member requests and repeated requests provide strong motivation. One interviewee had at least 10 customer inquiries before committing time and resources to the possibility of a PV-specific product. Conversely, in markets with barriers to PV adoption, CRFIs may be limited in their ability to stimulate PV demand, but they may alleviate a financing barrier by establishing a PV loan product. Commercial PV installations seem to have fewer dedicated lending products compared with the residential sector.

The motivations to offer PV loan products extend beyond requests from potential borrowers. Some CRFIs see promotion of PV as part of their commitment to environmental offerings or a triple-bottom-line (social, environmental, financial) business philosophy. Others see PV loans as an opportunity to grow the institution's lending portfolio or interact with new customers who might also be directed to the institution's other services.

In some cases, home-improvement contractors who banked with a CRFI asked the institution to create a PV loan offering, so they could recommend the product to their customers. Experience lending for similar home-improvement measures also drives PV loan product development or innovation. Several interviewees suggested PV loans complement existing home-improvement products. The interviewees generally reported positive experiences with energy efficiency lending (e.g., new windows, heating, ventilating, and air conditioning) and thought PV has a similar risk and performance profile. Some institutions came to PV lending through other PVspecific products, such as PACE financing or community PV projects. Several institutions entered the market in response to an attractive support policy, such as a state-based loan loss reserve fund for PV lending.

\subsection{PV Loan Product Development Benefits from a Thoughtful Research, Approval, and Product-Rollout Period}

All interviewees noted the need to devote considerable time and resources to understanding and developing a dedicated PV loan product. The education process typically entails a designated product lead researching the PV industry generally (technology, construction, pricing, risks, and reliability), the financing options available to local borrowers, the risks associated with PV lending, national and local competition, and the types of PV loans. As one banker noted, an overarching rule of banking is to know your product, know your market, and know your 
collateral. This industry research phase typically requires 6 months to 1 year, depending on the financial institution's familiarity with the PV industry.

There are multiple ways to develop a solar loan product. At some institutions, research is driven by an opportunistic, entrepreneurial and environmentally minded staff member (such as a loan officer) who champions the process, secures internal resources, and obtains decision-maker approvals. At other institutions, a management-level product-development officer (i.e., the chief lending officer or chief credit officer) provides the primary market research and justification for the product. In many cases, research and product development is driven by internal personnel. However, in some cases, an outside specialist with experience in the specific product class is hired to develop the product.

The internal champion often uses a concise product brief to secure internal approval, which can include approval by the chief credit officer, chief financial officer, loan and finance committee members, and potentially the board of directors. The brief can include information on local customer interest in the product, an assessment of the competitive lending landscape and market share, information on the technology and asset class, investigations into the local installer base, and a qualitative risk matrix. Decision makers scrutinize the loan tenors, which tend to be longer for PV than for other products, and the typical loan sizes among other criteria.

CRFIs frequently protect themselves against the unknowns of a new asset class by establishing a smaller initial loan product offering or portfolio concentration limits. Thus, they can roll out the program with relatively modest expectations and allow for a testing period, which can be reassessed later in the product-development cycle (often 1 or 2 years after program launch). Finding the right product balance is often part of the initial rollout. Too much volume, and the institution might feel uncomfortable with the portfolio concentration. Too little volume, and the time and setup costs are harder to justify.

\subsection{Smaller CRFIs Possess Unique Challenges and Opportunities}

It can be challenging for smaller CRFIs to establish a large portfolio of new loan products. Many have no dedicated product-development personnel, so personnel with other job duties must be tasked with establishing new loan products. In addition, because smaller institutions offer relatively few loans and cannot be over-weighted in any area (owing to concentration risk), the number of PV loans they can make may be limited, especially since there is a learning curve associated with a new asset class. Such limitations are particularly relevant for unsecured loans, because CRFIs are required to establish a loan loss reserve in case of default, which represents money not earning a return. A new product at a larger CRFI would represent a much smaller share of the total loan portfolio. Finally, the effort required for any product subject to significant regulations, such as real estate loans, may outweigh the product's benefits for a smaller institution without the dedicated capabilities to manage new requirements.

On the other hand, CRFIs have some advantages related to implementing PV loan products. Product approval processes can be easier at smaller institutions than at larger institutions. Smaller CRFIs may also be subject to less intense regulation compared with larger CRFIs. In addition, smaller CRFIs generally report the ability to be more nimble and adaptable when creating or modifying new products for a specific asset class like PV. 


\subsection{PV Loan Products and Processes Vary across Institutions}

Section 2.2 provides basic information about PV loan types. This subsection describes additional PV product variations across CRFIs.

CRFIs offer PV loans via direct and indirect lending programs. In the direct model, the lending institution provides capital to the borrower, and the borrower is typically free to choose a PV installer that meets minimum criteria (years in business, acceptable business ratings, applicable experience, etc.). Direct-lending customers are often existing members of the credit union or community bank or join specifically to take advantage of the loan offering. In the indirect model, the lending institution instead prequalifies select PV installers-typically based on requirements set by the institution - who can present the loan product on behalf of the institution. The indirect model gives the institution some control over the installation process and the borrower's experience with it.

PV loan programs evolve over time. Interviewees commonly reported launching a product, receiving customer and installer feedback during rollout, and making product adjustments accordingly. For example, several CRFIs adjusted to longer repayment periods or moved from a secured loan based on a second mortgage to a UCC-1 or unsecured loan.

PV loan products can include one or two loans per transaction. With two loans, the first amount is sized at approximately $30 \%$ of the PV purchase price to match the expected ITC amount, and the second funds the balance of the purchase price. The first loan can forego interest payments for the first 12-18 months (or the interest is paid by the installer), and the borrower can use their ITC benefit to pay off the zero-interest loan. The conventional second loan entails a standard amortization schedule (10-20-year term) and market interest rates. With one loan, for the full purchase price (at a set interest rate and term), the lender often offers a one-time reamortization for free or at a reduced rate (e.g., \$100), allowing the borrower to use the ITC or other funds to pay down the principal. This prepayment reduces the monthly payments while maintaining the original loan schedule. However, in this model, the borrower pays interest on the full loan amount before the principal paydown, while interest is typically paid on only $70 \%$ of the full loan in the two-loan approach.

The other timing element in structuring a solar loan product is the disbursement schedule from the bank to the installer. For example, one program disburses 35\% of the loan amount once the loan has been closed and then the final 65\% after installation. Installers may prefer a more frontloaded disbursement schedule, while lenders typically prefer holding funds until after installation.

Loan application and closing processes also vary. Some CRFIs primarily handle customer applications over the phone, whereas others allow online applications through a dedicated portal connection. Some banks work with PV installers and developers to integrate the online portal into the PV sales process. Variations in closing processes include fully automated versus manual review and approval as well as online document signing versus finalizing loans in person at a branch and, in some cases, in the presence of an attorney.

Finally, options to improve loan terms vary. Attractive sales pitches can include low interest rates or a "no interest" period (e.g., the first year) that allow borrowers to save money 
immediately instead of waiting for energy savings from PV (e.g., in the winter, when electricity production is lower). The no-interest period is particularly attractive in the first year, before the loan's principal is reduced through an ITC buydown. These practices are done per strict lending regulation. However, borrowers should analyze all loan conditions including interest rates, terms, penalties, and fees-which lenders can charge to the borrower or the PV developer, who may pass the fee on to the PV sales price.

\subsection{UCC-1 Fixture Filing Is Useful as a Security Interest, but Repossessing PV Systems Is Impractical}

Most CRFIs that offer a dedicated PV loan use a UCC-1 fixture filing, and many institutions have had positive experiences with this process. Interviewees commonly described the usefulness of the UCC-1 fixture filing not in terms of collateral recoverable via repossession, but rather as an indicator that the PV system has an outstanding loan to be paid, which is often revealed at the time of a home sale or refinancing. The UCC-1 fixture filing provides some protection from a loss due to loan default, even if the lender must wait an extended time (sometimes years for a home sale) to potentially recover some portion of the debt. UCC-1 fixture filing is not, however, a one-time process; lenders typically must refile every 5 years to maintain protections.

Lenders can try to repossess PV systems, but most interviewees questioned the practicality of this approach for several reasons. First, CRFIs have little use for a used PV system, andbecause there is no established secondary market for used PV equipment-attempting to liquidate a PV system might yield little return. In contrast, when a UCC-1 filing is used to secure a loan for commercial equipment such as heavy machinery or vehicles, the repossession value is relatively high owing to the equipment's mobility and the active secondary market for used equipment. Second, the all-in cost of a PV system (and thus the loan amount) reflects not only the equipment cost, but also various "soft costs" related to system design, installation labor, permitting, customer acquisition, and so forth. Repossessing the PV equipment would not compensate for these soft costs. At the same time, uninstalling, storing, and selling the used PV equipment (while preserving the roof's integrity) would be costly to the lender. Finally, and perhaps most importantly, trying to repossess PV equipment from a distressed borrower's home presents a risk of bad publicity.

\subsection{PV Loan Repayment Has Been Strong, but Most Loans Are Young and Were Made to Highly Rated Borrowers}

All interviewees reported positive results from their PV loan portfolios, with no portfolio-wide issues or systematic concerns to date and only a few repayment anomalies attributed to events such as divorces, bankruptcies, or deaths of the primary borrowers. Interviewees described their PV loans' performance with phrases such as "pretty good overall," "little to no losses to speak of but a few delinquencies," "charge-offs remaining unbelievably low," and "delinquencies and 
losses lower than expectations.” ${ }^{14}$ Because of high repayment performance to date, many CRFIs will increase the volume of PV loans offered.

However, the high performance of PV loans must be qualified. First, PV loan recipients were, on average, considered A+ borrowers and thus were expected to pay reliably. Some interviewees questioned whether borrowers with lower credit quality would do as well; some CRFIs are considering expanding their PV loan offerings to borrowers with slightly lower credit quality, but they are limited by the need for such borrowers to own homes. Second, the PV loan programs are generally young, and thus many loans are very early in their tenor. Many interviewees said delinquencies or losses from comparable loan products typically peak later, perhaps between years 2 and 5 of the loan. Finally, because the current economy is extremely robust, the performance of PV loans during a downturn is uncertain. Kroll Bond Rating Agency stated in its rating of a securitized portfolio of residential loans from a large solar provider that, "with no more than 36 months of performance data [typical for most solar loan programs] ... these loans have not been through a full loan-cycle and therefore losses could be higher than experience to date suggests” (KBRA 2018).

See Section 4 for a quantitative summary of PV loan performance to date.

\subsection{Relationships between PV Installers and CRFIs Can Enhance the Marketing of PV Loan Products}

Interviewees consistently described the critical role of PV installers in driving the demand for PV loan products. Because, as one interviewee said, customers typically decide to install PV first and then search for financing products, many potential customer inquiries are directed to installers as opposed to finance providers.

PV installers and CRFIs both market PV loan programs. Product marketing channels include social media, newsletters, direct mailings, farmers markets, movie theater advertisements, coupon books, and home shows. Some interviewees described a shift in the way most loan leads have been generated as PV loan products have evolved. Early in the loan programs, some existing bank and credit union members contacted their CRFIs to finance PV. As new sales channels have been made, CRFIs have developed relationships with installer partners that bring in customers who may not have been CRFI members.

Being comfortable with installer partners is very important. Installers may have exclusive agreements pertaining to a CRFI's financial product and may have online access to the loanorigination system to close the deal. A CRFI can save underwriting time, help installers understand and promote loan products, and mitigate technology and installer risks by pre-vetting PV installers and developing relationships with vetted installers in the CRFI's service territory. The CRFI and installer both benefit from communicating about areas of concern and teaching each other their business languages. Although installers do not qualify borrowers, training enables them to speak with potential borrowers about the financial product, process, and

\footnotetext{
${ }^{14}$ Charge-offs generally refer to the situation in which a lender records a monetary loss on a loan due to nonrepayment.
} 
relationships. Alternatively, an installer may simply provide the customer with a sample of financial product offerings (loan brochures, etc.) to choose from.

\subsection{CRFls Are Willing to Extend PV Loans to Lower-Rated Borrowers, but Barriers Exist}

Although to date PV loan recipients have generally had high financial qualifications, interviewees agreed that offering loans to less highly rated customers, within reason, is desirable. Having a more extensive and detailed national history of PV loan credit performance would help this effort. In addition, having more granular data (e.g., at the county or state level) would likely be required to drive local financing decisions. The automobile industry provides a good example of easy access to credit data, with high regional fidelity and extensive history.

The primacy of the federal ITC as a residential PV incentive may hinder the offering of PV loans to customers with lower financial ratings. In many cases, low- to moderate-income customers may not benefit directly from a tax credit due to insufficient tax liabilities. In such cases, a TPO arrangement rather than direct PV ownership might be more appealing because the TPO provider can monetize the tax credit.

Naturally CRFIs want to extend loans that borrowers can repay with relative ease and consistency. After the recent mortgage crisis and ensuing regulations, lending institutions assumed additional fiduciary and legal responsibility to deny loans to customers who cannot service them. Although many government programs target low- and moderate-income customers, CRFIs are hesitant to push the bar too low for challenged borrowers. In any case, customers living paycheck to paycheck may be less interested in products like PV that offer savings over a 15-year period or longer.

That said, PV loan approval processes are not necessarily determined by hard and fast rules tied to credit scores or debt-to-income ratios. Because CRFIs know their market and customer base well, they can examine customers individually and evaluate loan products that make sense for the borrower and lender. Interviewees, however, did report that they frequently declined customers based on insufficient financial qualifications.

\subsection{PV Energy Savings Are Generally Given Little Weight during Loan-Approval Processes}

Although PV owners save on utility payments, many CRFIs generally do not factor these savings into PV loan criteria. Most financial institutions use a debt-to-income ratio to assess a borrower's ability to repay debt. Taking out a PV loan increases the debt side of that ratio, while acquiring a PV system increases the income side (through energy savings) - yet the PV income factor is generally not considered during loan qualification.

Because of this practice, government policies that affect PV economics might have a muted impact on CRFI decisions to offer a PV loan. For example, reducing PV's economic value by lowering the net metering rate might reduce the demand for PV loans, but it would not directly change a loan's evaluation criteria. That said, energy bill savings are sometimes factored in to the process of deciding whether to offer a PV loan product, even if they are not formally included as part of the loan-approval process. CRFIs may also be more inclined to include these 
savings in their analysis if they had access to widely accepted third-party guidance on the specifications that determine how much a PV system will reduce a customer's electricity bill. This type of documentation would be particularly beneficial for banks entering the space in markets without significant PV deployment.

\subsection{Regulations Have Not Hindered PV Loans, but Educating Regulators about PV May Help}

Various entities regulate CRFIs, including the FDIC (which insures deposits for local and regional banks), the NCUA (which insures deposits for credit unions), any number of state-based financial regulators (particularly for CRFIs with a state charter), federal regulators (such as the Office of the Comptroller of the Currency), and more. Some entities may overlap, and a single institution may be regulated or monitored by multiple agencies.

In general, interviewees identified no significant regulatory barriers related to PV loans. Regulators aim to ensure that loans do not harm the safety and soundness of the institution (because these regulators serve as guarantors of institution deposits) and that the consumer is protected against predatory or discriminatory lending practices. Thus, CRFIs must demonstrate how PV loans fit under those requirements, for example, by demonstrating clear and fair lending practices, a satisfactory credit quality of the overall portfolio, appropriate disclosures that are clear and sufficient, and that institutions are not over-weighted in any one market or customer segment (which can introduce portfolio-concentration risk).

Educating regulators about PV loans can facilitate regulatory review of CRFI portfolios. Most interviewees agreed that regulators do not approve PV loan programs before program initiation. Instead, PV loans are established under the same practices and general regulations that are applied to all other loan types. However, regulators might review an institution's entire loan portfolio annually or at other intervals, in which case it can be helpful to educate the regulators about the PV asset class. Some CRFIs work with outside partners to prepare for the audit process, which can last a week or more. In any case, product innovation outside of an industry standard, such as a 15-year equipment loan on PV, can happen if it fully conforms to regulations.

\subsection{Challenges Remain for PV Loan Products}

There are a few remaining challenges to CRFI development of PV loan products. For example, the term of a PV loan (up to 20 years) presents long-term interest rate risk, because interest rates could change while the loan's rate stays fixed. Some CRFIs are more comfortable assuming this risk than others. Risk-mitigation measures include shorter terms, higher rates, or one-time rate adjustments, but these measures can make the loan less attractive to borrowers.

The lack of an established securitization market for PV loans is another challenge. Although some PV loans from national installers have been sold on the securities market, most CRFIs do not have the size or volume to sell PV loans to the securities markets. Most interviewees said they would prefer to keep PV loans rather than sell them. However, the option to sell a portfolio 
of loans to other investors could lower risks by creating more liquidity, thus putting PV loans on equal footing with loans for more established asset classes such as mortgages and automobiles. ${ }^{15}$

PV loans with UCC-1 fixture filings can also entail challenges. Some lenders cannot offer such loans when the PV-hosting house is held in trust rather than in the borrower's name. In addition, because PV loans with UCC-1 fixture filings are not as widely familiar as secured loans (HELOCs, second mortgages) or unsecured, personal loans, the lender's requirements do not always meet the borrower's expectations.

Finally, the lack of national and local information about PV loans makes it difficult for CRFIs to assess market size and the risks of starting a PV loan program. Whereas market research firms provide robust data for other asset classes, such as automobile loans, the smaller PV market has not yet stimulated the development of detailed, widely available data products. ${ }^{16}$

\footnotetext{
${ }^{15}$ June 2017 guidance from the NCUA asserts that federal credit unions are authorized to issue and sell assets such as Ginnie Mae home mortgages, auto loans, and other assets (NCUA 2017). The practice, known as securitization, was not explicitly authorized for federal credit unions prior to the 2017 guidance. Securitization of assets by community banks is estimated at more than $\$ 28$ billion in 2014 though small relative to total assets (Baily and Montalbano 2015). In general, securitization by CRFIs may be limited to larger institutions with asset volumes large enough to justify the transactional costs and expertise required.

${ }^{16}$ Previous NREL efforts targeted this data gap for the TPO market, but not for solar lending (NREL 2018).
} 


\section{Quantitative Indicators of PV Loan Performance}

This section provides summary statistics on PV loans made by CRFIs to complement the qualitative insights noted above. The data are anonymized and used to analyze loan and borrower characteristics as well as loan performance.

The data set contains high-level information from 6,770 loans, representing a combined PV loan portfolio exceeding \$186 million across 22 different CRFIs. Massachusetts accounts for 57\% of the PV loans in the data set and $67 \%$ of the loan value. These data were collected by the Massachusetts Clean Energy Center (MassCEC) and the Massachusetts Department of Energy Resources as part of the Mass Solar Loan Program (Mass Solar Loan 2018). NREL collected data for the remaining $43 \%$ of PV loans and 33\% of loan value from individual CRFIs across the United States. Across the entire combined data set (6,770 loans), banks account for 32\% of the PV loans and $38 \%$ of the loan value, and credit unions constitute the remaining $68 \%$ of PV loans and 62\% of loan value. The loan data reflect performance through February 2018.

These data entail several caveats. The PV loan program data were self-reported by the various CRFIs. Although the data were spot checked, a thorough audit to check consistency across institutions or for reporting accuracy was not conducted. The Mass Solar Loan Program data are part of a state incentive program that includes a financially protective loan loss reserve fund, which may impact lending practices such as borrower qualification and the interest rate. The institutions outside the Mass Solar Loan Program reported data through a standardized form, but each institution may collect and process their PV lending data uniquely, which could produce subtle data differences across institutions. Thus, the data are useful for analyzing high-level trends. Future studies could improve the data-collection process and expand the scope of the analyses.

Table 2 categorizes the data by the value of each institution's PV loan portfolio. Out of 6,770 total PV loans, 12 loans ( $<0.2 \%$ ) were reported as charge-offs, indicating the loan is unlikely to be repaid by the borrower. Hypothetically, if an average lender charged-off $\$ 15,000$ for each of the 12 defaulted loans, the loss would represent about \$26 per loan when spread across all 6,770 loans. This estimate is likely high, because some loan charge-off losses could be offset from a claim to a loan loss reserve program or via the UCC-1 process when the home is sold or refinanced.

Table 2. PV Loan Sample Summary Statistics by CRFI Portfolio Size

\begin{tabular}{|c|c|c|c|c|c|c|c|c|c|c|c|}
\hline $\begin{array}{l}\text { PV loan } \\
\text { portfolio } \\
\text { (million) }\end{array}$ & $\begin{array}{l}\text { No. of } \\
\text { CRFIs }\end{array}$ & $\begin{array}{l}\text { Total } \\
\text { loans }\end{array}$ & $\begin{array}{l}\text { No. of } \\
\text { loans }\end{array}$ & $\begin{array}{c}\text { Avg. } \\
\text { seasoning } \\
\text { in } \\
\text { months }\end{array}$ & $\begin{array}{l}\text { FICO } \\
\geq 720\end{array}$ & $\begin{array}{c}\text { FICO } \\
681- \\
719\end{array}$ & $\begin{array}{l}\text { FICO } \\
\leq 680\end{array}$ & $\begin{array}{c}\text { Charge- } \\
\text { offs }\end{array}$ & $\begin{array}{c}30 \\
\text { days } \\
\text { late }\end{array}$ & $\begin{array}{c}60 \\
\text { days } \\
\text { late }\end{array}$ & $\begin{array}{c}90 \\
\text { days } \\
\text { late }\end{array}$ \\
\hline$>\$ 10$ & 6 & $\$ 138,699,859$ & 4,929 & 12 & $78 \%$ & $14 \%$ & $8 \%$ & 10 & 171 & 61 & 24 \\
\hline$>\$ 5-\$ 10$ & 4 & $\$ 30,867,895$ & 1,091 & 13 & $82 \%$ & $11 \%$ & $6 \%$ & 0 & 4 & 0 & 0 \\
\hline$>\$ 1-\$ 5$ & 6 & $\$ 13,886,826$ & 658 & 14 & $76 \%$ & $12 \%$ & $11 \%$ & 2 & 0 & 0 & 0 \\
\hline$<\$ 1$ & 6 & $\$ 2,851,725$ & 92 & 4 & $88 \%$ & $9 \%$ & $3 \%$ & 0 & 3 & 0 & 0 \\
\hline Totals & 22 & $\$ 186,306,305$ & 6,770 & & & & & 12 & 178 & 61 & 24 \\
\hline
\end{tabular}

Source: Mass Solar Loan 2018 and individual CRFI contributions 
There were 178 loans reported at least 30 days late, representing approximately $2.6 \%$ of the overall loan portfolio. Interviewees noted that short-term delinquencies can occur when borrowers are slow to set up automatic loan payments. Delinquencies drop substantially at the 60- and 90-day marks. ${ }^{17}$ According to some interviewees, loan delinquency rates may vary by loan "seasoning" (i.e., the time elapsed since loan closing). For example, delinquencies might be expected to peak at 2-5 years of seasoning according to some interviewees. As shown in Table 2 and Figure 4, most PV loans in the data set were substantially younger than 2 years. The lower seasoning of CRFIs with portfolios of \$1 million or less compared with the rest of the institutions could indicate smaller institutions or relatively nascent solar loan program offerings.

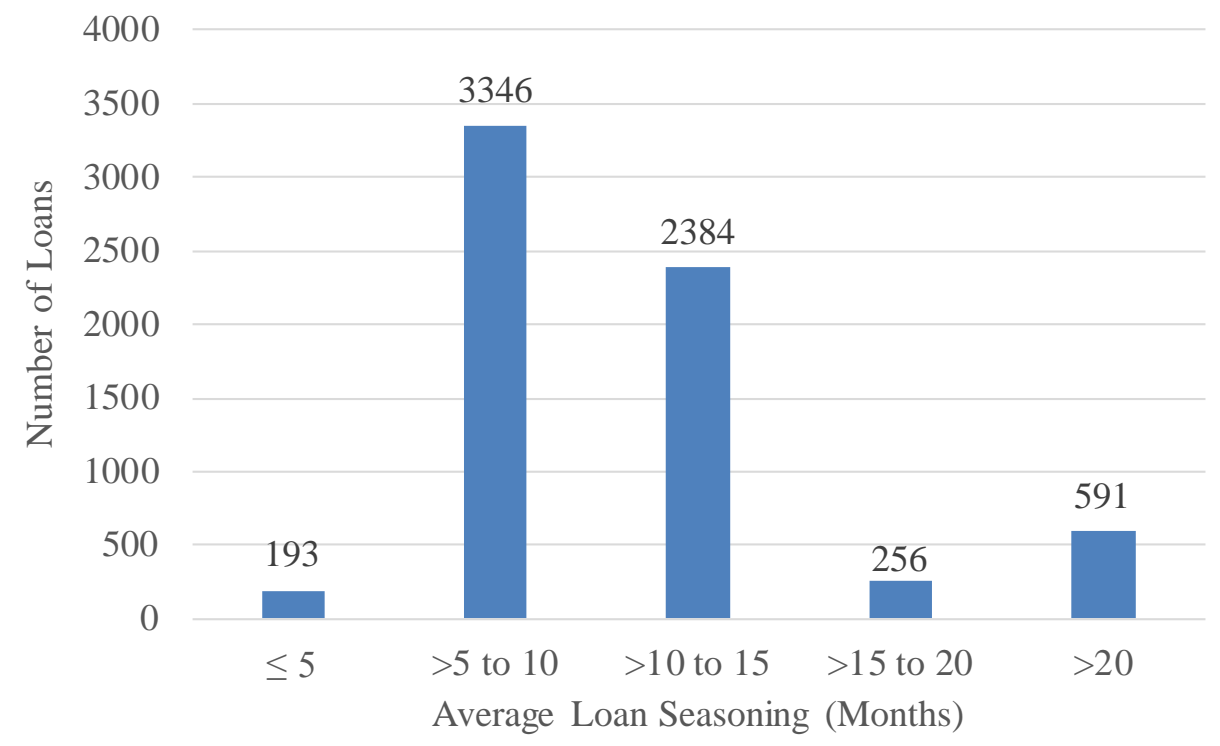

Figure 4. Number of CRFI PV loans by seasoning ${ }^{18}$

Table 2 also summarizes borrower credit profiles, which are consistent across CRFIs of various PV loan portfolio sizes: $76 \%-88 \%$ of borrowers had credit scores of 720 or higher, $9 \%-14 \%$ had scores of $681-720$, and 3\%-11\% had scores of 680 or lower. Even within the lowest credit category, many borrowers likely were still considered "prime" - that is, attractive enough to qualify for approval at relatively low interest rates. The "subprime” level typically starts around a 620-credit score. These statistics agree with interviewees describing typical PV borrowers with overall high credit quality, thus presenting less risk. The high credit quality of PV borrowers is

\footnotetext{
${ }^{17}$ Some institutions report cumulative delinquency payments (how many loans have ever been late even if they are now current), whereas others report point-in-time delinquency metrics (how many loans are delinquent at any given point in time). Thus, the delinquency data in Table 2 are likely higher than if all the reported delinquencies were based on point-in-time estimates, because many delinquencies are corrected over time. Conversely, the delinquency data in Table 2 are likely lower than they would be if each financial institution reported a cumulative metric showing the number of loans that have ever been delinquent during the loan's operating period.

${ }^{18}$ Loan seasoning for Mass Solar Loan Program data is provided at the individual loan level, which is then averaged for each CRFI. Loan seasoning for CRFIs outside of the Mass Solar Loan Program is provided as a portfolio average for that CRFI. The number of loans shown in Figure 4 represents the total number of loans in each bin including both Mass Solar Loan Program and other CRFI data.
} 
also expected, because applicants must be homeowners and ideally have enough income to use the ITC effectively. Figure 5 provides a credit score summary of the total sample.

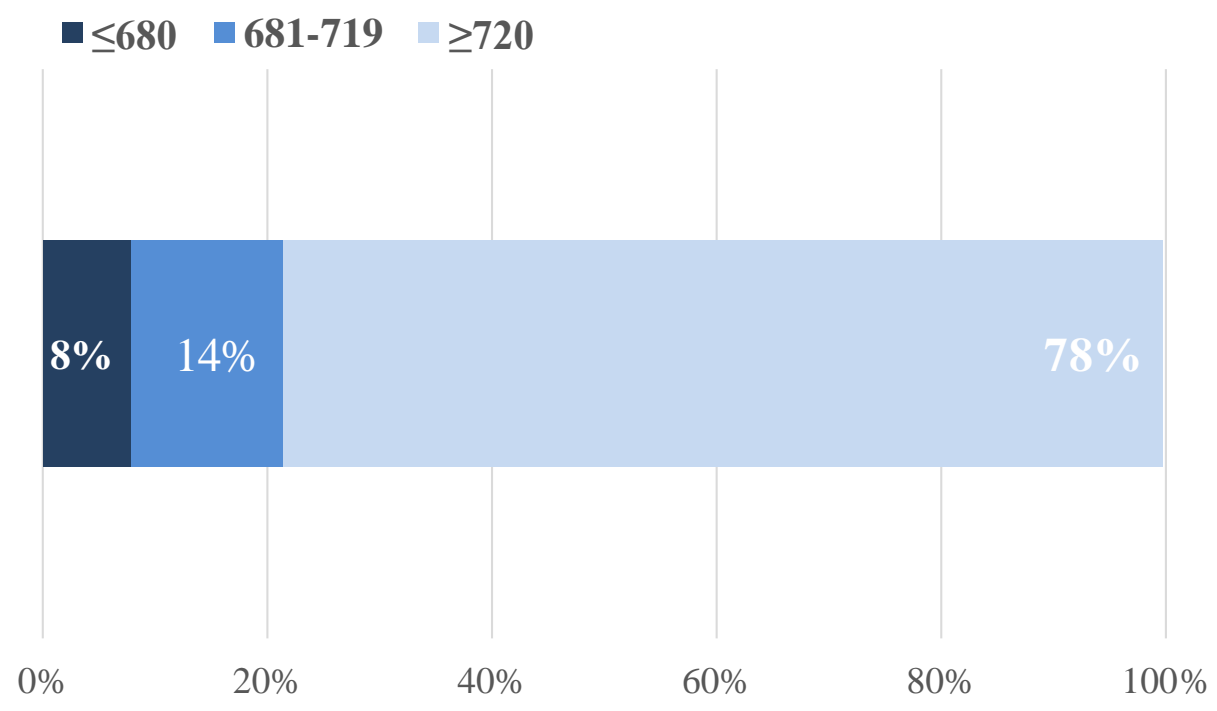

Figure 5. Credit score summary across entire sample of borrowers 


\section{Conclusions and Future Needs}

CRFIs have demonstrated the willingness and entrepreneurism to provide new loan products for growing distributed PV markets. Early qualitative perspectives and quantitative data suggest PV loans are performing very well, making expansion of loan offerings attractive for CRFIs already operating in this space and potentially attracting new entrants. Although most CRFI investment to date has targeted standalone distributed PV, other applications will likely emerge, such as community PV and PV coupled with battery storage.

Access to additional credit and market information is critical for accelerating the role of CRFIs and other financial institutions in supporting U.S. PV growth, including the following:

- Higher-fidelity PV loan performance and borrower credit data on par with the data readily available for other assets classes, especially improved geographic, historical, and borrower-classification data.

- Information on the presence of PV financing providers across different markets as well as detailed information on the type of financing products provided.

- Information provided through dedicated PV lending training or educational materials to existing and potential PV lenders, covering areas such as technical evaluation of PV equipment, assessment of industry risk profiles, and characterization of various PV financing products.

Public and private partnerships may be able to collect and disseminate such data throughout the United States. Working together, the industry can help existing providers grow their loan portfolios and reduce risks while enabling new financiers to enter the PV loan space and service areas where distributed PV loans can be offered widely and profitably. 


\section{References}

Baily, Neil M., and Nicholas Montalbano. 2015. The Community Banks: The Evolution of the Financial Sector, Part III. The Brookings Institution. December. https:/www.brookings.edu/wpcontent/uploads/2016/07/Community_Banks_Baily_Part_III-2.pdf.

CUNA (Credit Union National Association). 2017. “U.S. Credit Union Profile: Year-end 2017.” Accessed April 23, 2018. https://www.cuna.org/About-Credit-Unions/Credit-Union-Data--Statistics/.

EIA (U.S. Energy Information Administration). 2018. Annual Energy Outlook 2018.

Washington, DC: EIA. https://www.eia.gov/outlooks/aeo/.

FDIC (Federal Deposit Insurance Corporation). 2012. "FDIC Community Banking Study.” Accessed April 23, 2012. https://www.fdic.gov/regulations/resources/cbi/study.html.

FDIC. 2015. "Brick-and-Mortar Banking Remains Prevalent in an Increasingly Virtual World.” FDIC Quarterly 2015 9, no. 1. https://www.fdic.gov/bank/analytical/quarterly/2015-vol9-1/fdic4q2014-v9n1-brickandmortar.pdf.

FDIC. 2017. “Statistics at a Glance: as of December 31, 2017.” Accessed April 23, 2018. https://www.fdic.gov/bank/statistical/stats/.

FDIC. 2018. “Quarterly Banking Profile: Fourth Quarter 2017.” FDIC Quarterly 2018 12, no. 1. https://www.fdic.gov/bank/analytical/qbp/qbpmenu.html.

Feldman, David., and Travis Lowder. 2014. Banking on Solar: An Analysis of Banking Opportunities in the U.S. Distributed Photovoltaic Market. NREL/TP-6A20-62605. Golden, CO: National Renewable Energy Laboratory. https://www.nrel.gov/docs/fy15osti/62605.pdf.

Fuster, A., Andrew Haugwout, Nima Dahir, and Mike Neubauer. 2018. Survey of Consumer Expectations: Housing Survey-2018. New York: Federal Reserve Bank of New York.

https://www.newyorkfed.org/medialibrary/interactives/sce/sce/downloads/data/FRBNY_SCE_H ousing_chartpacket2018.pdf.

Harney, K. 2018. “Did the tax code overhaul kill home equity loans?” Washington Post, January 17. https://www.washingtonpost.com/realestate/did-the-tax-code-overhaul-kill-home-equityloans/2018/01/16/626f8054-facf-11e7ad8cecbb62019393_story.html?utm_term=.ea60b1c518a3.

International Association of Commercial Administrators (IACA). 2018. "UCC Forms.” Accessed June 11, 2018. https://www.iaca.org/secured-transactions/forms/.

KBRA (Kroll Bond Rating Agency). 2018. Mosaic Solar Loan Trust 2018-1. New York: KBRA.

Mass Solar Loan. 2018. Mass Solar Loan Program Performance Information. Data accessed March 13, 2018. 
Mond, A. 2018. U.S. Residential Solar Finance Update, H1 2018. Boston: GTM Research.

NCUA (National Credit Union Administration). 2017. Authority to Issue and Sell Securities. June, 21. 2017. https://www.ncua.gov/regulation-supervision/Pages/rules/legalopinions/2017/asset-securitization-authority.pdf.

NREL (National Renewable Energy Laboratory). 2018. "Renewable Energy Project Finance: Solar Securitization and the Solar Access to Public Capital (SAPC) Working Group.” Accessed April 23, 2018. https://financere.nrel.gov/finance/content/solar-securitization-and-solar-accesspublic-capital-sapc-working-group\#standard_contracts.

SEIA and GTM Research (Solar Energy Industries Association and GTM Research). 2018. U.S. Solar Market Insight: 2017 Year-in-Review. Washington, DC: SEIA. 